\title{
Isolation of Surfactant-Resistant Pseudomonads from the Estuarine Surface Microlayer
}

\author{
Louvado, António ${ }^{1}$, Francisco J. R. C. Coelho ${ }^{1}$, Patrícia Domingues ${ }^{1,2}$, Ana L. Santos ${ }^{1}$, Newton C. M. Gomes ${ }^{1}$, \\ Adelaide Almeida ${ }^{1}$, and Ângela Cunha ${ }^{1 *}$
}

${ }^{1}$ Department of Biology and CESAM, University of Aveiro, Campus de Santiago, 3810-193 Aveiro, Portugal

${ }^{2}$ Department of Chemistry, University of Aveiro, Campus de Santiago, 3810-193 Aveiro, Portugal

Received: October 13, 2011 / Revised: November 16, 2011 / Accepted: November 17, 2011

Bioremediation efforts often rely on the application of surfactants to enhance hydrocarbon bioavailability. However, synthetic surfactants can sometimes be toxic to degrading microorganisms, thus reducing the clearance rate of the pollutant. Therefore, surfactant-resistant bacteria can be an important tool for bioremediation efforts of hydrophobic pollutants, circumventing the toxicity of synthetic surfactants that often delay microbial bioremediation of these contaminants. In this study, we screened a natural surfactant-rich compartment, the estuarine surface microlayer (SML), for cultivable surfactant-resistant bacteria using selective cultures of sodium dodecyl sulfate (SDS) and cetyl trimethylammonium bromide (CTAB). Resistance to surfactants was evaluated by colony counts in solid media amended with critical micelle concentrations (CMC) of either surfactants, in comparison with non-amended controls. Selective cultures for surfactant-resistant bacteria were prepared in mineral medium also containing CMC concentrations of either CTAB or SDS. The surfactantresistant isolates obtained were tested by PCR for the Pseudomonas genus marker gac $A$ gene and for the naphthalene-dioxygenase-encoding gene ndo. Isolates were also screened for biosurfactant production by the atomized oil assay. A high proportion of culturable bacterioneuston was tolerant to CMC concentrations of SDS or CTAB. The gac $A$-targeted PCR revealed that $64 \%$ of the isolates were Pseudomonads. Biosurfactant production in solid medium was detected in $9.4 \%$ of tested isolates, all affiliated with genus Pseudomonas. This study shows that the SML is a potential source of surfactant-resistant and biosurfactant-producing bacteria in which Pseudomonads emerge as a relevant group.

Keywords: Bacterioneuston, surfactants, biosurfactants, Pseudomonas, surface microlayer

* Corresponding author

Phone: +351234 370 784; Fax: +351 234372 587;

E-mail: acunha@ua.pt
Bioremediation is considered an efficient, cost-effective, and versatile alternative to physical and chemical treatments of hydrocarbon contamination [65], and bacteria are suitable for biodegradation because they adapt to a wide variety of carbon sources and electron acceptors [71]. However, because of the hydrophobic nature of hydrocarbons, the microbial degradation is limited by their reduced solubility and consequent low bioavailability [54]. A possible process of enhancing the availability of oil hydrocarbons is the use of surfactants. Surfactants reduce surface and interfacial tension and lead to the formation of microemulsions in which hydrocarbons can solubilize in the water, increasing their bioavailability [4]. However, the addition of chemical surfactants often fails to enhance the rate of biodegradation of hydrophobic compounds $[8,50,59,69,82]$ because of surfactant toxicity to bacteria [65], and also because the surfactant may be used as a carbon source outcompeting hydrocarbons as sustrates for bacterial growth [69].

An effective bioremediation strategy is the use of bacteria capable of thriving in the presence of surfactants [54]. Alternatively, consortia of efficient biosurfactant-producing bacteria and hydrocarbonoclastic microbes can be employed, improving bioremediation efforts $[58,71]$. This aim has triggered the intense search for biosurfactant-resistant bacteria in surfactant-rich environments, and some studies have demonstrated a high frequency of biosurfactants producers among surfactant-resistant isolates [54]. Biosurfactant production is a mechanism by which microorganisms adapt to interfacial challenges [70]. Biosurfactants are often produced by hydrocarbon-degrading bacteria as an adaptation to the low bioavailability of hydrophobic pollutants [58] or by biofilm-forming microorganisms, such as Pseudomonads (i.e., P. aeruginosa) [15]. Because of their environmental and technical advantages relative to their synthetic counterparts [56], biosurfactants have gained biotechnological and economical interest. Therefore, the prospection for new biosurfactants-producing strains has more recently been 
directed to hydrocarbon-contaminated sites $[63,72]$, marine environments [54, 63], and uncommon or extreme microbial habitats [36, 40, 71]. Pseudomonads include oil-degrading and biosurfactant (rhamnolipids)-producing strains and are frequently found in oil-impacted marine sites [27].

The surface microlayer (SML) is the uppermost millimeter of the water column, and bacteria living in this compartment (bacterioneuston) face a challenging environment in terms of exposure to solar irradiation, accumulation of pollutants, and surface tension [2]. However, bacterioneuston is often reported to reach higher cell abundance than the underlying bacterioplankton, suggesting an effective adaptation to this extreme environment $[2,19]$. The SML is simultaneously enriched in biosurfactants [79] and hydrophobic contaminants [73], representing an environment where surfactant-resistant and biosurfactant-producing bacteria with the desired biodegradative capabilities are likely to be found.

The primary aim of this work was to screen a natural surfactant-rich environment, the SML, for surfactant-resistant culturable bacteria and to detect eventual biosurfactant producers and hydrocarbon degraders among bacterial isolates, envisaging biotechnological applications. A particular focus was set on Pseudomonads, considering that hydrocarbon degradation $[4,39]$ and biossurfactant production are well documented among members of this group [78].

\section{Materials And Methods}

\section{Surface Microlayer Sampling}

Estuarine surface microlayer (SML) samples were obtained next to a shipping dock in Ria de Aveiro (northwest Portugal), a shallow (mean depth $1 \mathrm{~m}$ ) branched estuarine ecosystem, also described as a coastal lagoon [17]. SML water was collected using alternately a $0.25 \mathrm{~m}$ wide $\times 0.35 \mathrm{~m}$ Plexiglass and glass plates [28], which removed the upper $60-100 \mu \mathrm{m}$ water layer. Before sampling, the plates were rinsed with ethanol, distilled water, and several times with water from the sampling site. The plates were immersed and carefully removed from the water column in an upright position. After allowing the plates to drip for $5 \mathrm{~s}$, the water adhering to both surfaces was removed by forcing the plate between two Teflon wiper blades and collecting the water in sterilized glass bottles.

\section{Surfactant Resistance in Bacterioneuston}

For the quantification of culturable surfactant-resistant bacteria in the initial bacterioneuston community, cetyl trimethylammonium bromide (CTAB) and sodium dodecyl sulfate (SDS) were used as experimental models for cationic and anionic chemical surfactants, respectively. Serial dilutions of samples of SML water were spreadplated on triplicate plates of PY $(0.1 \%$ peptone and $0.01 \%$ yeast extract diluted in $17 \mathrm{PSU}$ brackish water) amended with critical micelle concentrations (CMC) of either CTAB (1 mM; Sigma) or SDS (8 mM; Bio-Rad). Non-amended PY medium was used as the control. Cultures were incubated at room temperature (approximately $22^{\circ} \mathrm{C}$ ) in the dark, for approximately $72 \mathrm{~h}$, and colonies were counted in the most suitable dilution.
The concentration of CFU in controls, and SDS- and CTABcontaining media were tested for normality (Kolmogorov-Smirnov test), and the significance of the differences was assessed by parametric analysis of variance (ANOVA) of normally distributed data with the SPSS software package.

\section{Selection and Isolation of Surfactant-Resistant Bacteria}

In parallel, two selective cultures were prepared using $200 \mathrm{ml}$ of SML sample and $800 \mathrm{ml}$ of basal saline medium (BSM) containing $0.5 \mathrm{~g} / 1 \mathrm{NaCl} ; 3.5 \mathrm{~g} / \mathrm{KH}_{2} \mathrm{PO}_{4} ; 0.5 \mathrm{~g} / 1 \mathrm{NH}_{4} \mathrm{Cl} ; 0.14 \mathrm{~g} / 1 \mathrm{NaSO}_{4} ; 1.5 \mathrm{~g} / \mathrm{l}$ $\mathrm{K}_{2} \mathrm{HPO}_{4}$; and $0.15 \mathrm{~g} / 1 \mathrm{MgCl}_{2} \cdot 6 \mathrm{H}_{2} \mathrm{O}$ in $17 \mathrm{PSU}$ brackish water, $\mathrm{pH}$ 7.1 [3]. The anionic surfactant SDS or the cationic surfactant CTAB $(1 \mathrm{mM})$ were added to each of the microcosms at $\mathrm{CMC}$ concentrations (approximately $8 \mathrm{mM}$ for SDS and $1 \mathrm{mM}$ for $\mathrm{CTAB}$ at $25^{\circ} \mathrm{C}$ and atmospheric pressure). The cultures were incubated aerobically at room temperature (aprox. $22^{\circ} \mathrm{C}$, which does not significantly affect the $\mathrm{CMC}$ ), for 8 weeks on a rotary shaker operating at $120 \mathrm{rpm}$. Microcosms were incubated at the dark in order to select for heterotrophic bacteria. After 14 and 28 days of incubation, the culture medium was renewed by adding $800 \mathrm{ml}$ of BSM to $200 \mathrm{ml}$ of preexisting culture. Aliquots were collected weekly (except in week 7) and spread-plated in triplicate on PY plates containing either SDS $(8 \mathrm{mM})$ or CTAB $(1 \mathrm{mM})$ for monitoring of the development of the surfactant-resistant community. After 3 days of incubation at $22^{\circ} \mathrm{C}$ in the dark, morphologically distinct colonies were selected and purified by successive streaking on surfactantamended PY plates (minimum 3 streaks).

\section{Detection of Biosurfactant Production in Isolated Strains}

Biosurfactant production was assessed in a set of 53 isolates by the culture-dependent atomized-oil assay [9]. Isolates were inoculated with a sterile toothpick on solid medium PY. After colony development, $n$-paraffin (Merck) was pulverized over the colonies at 1.02-1.36 atm using an airbursh (Fengda, model BD-128P). The formation of a halo surrounding the colonies was considered as indicative of biosurfactant production. Synthetic surfactants Tween 80 (Merck), CTAB (Sigma), and SDS (BioRad), and the biosurfactant surfactin (Sigma) were used as positive controls at concentration of $8.0 \mu \mathrm{M}, 0.2 \mathrm{mM}$, $10.0 \mathrm{mM}$, and $15.4 \mathrm{nM}$, respectively. A culture of Escherichia coli DH5 $\alpha$ was used as the negative control.

\section{Detection of Naphthalene-Dioxygenase-Encoding Genes in Isolated Strains}

DNA was extracted from pure cultures of a set of 53 isolates as described by Henriques et al. [29]. The gene ndo encodes the $\alpha$ subunit of the multicomponent enzyme system naphthalene dioxygenase, involved in aerobic degradation of low molecular weight PAH [23]. All isolates were tested for the presence of the $n d o$ gene by PCR (Multigene TC 9600-G thermocycler; Labnet International) using primers PAH-RHD $\alpha$ GNF (5'-GAGATGCATACCACGTKGGTTGGA3') and PAH-RHD $\alpha$ GNF (5'-AGCTGTTGTTCGGGAAGAYWG TGCMGTT-3') [11] (IBA GmbH, Germany). A $25 \mu 1$ reaction mixture was prepared using $1 \mu \mathrm{l}$ of template, $1 \mathrm{U}$ Taq polymerase, $1 \times \mathrm{PCR}$ buffer, $0.2 \mathrm{mM}$ dNTPs, $3.75 \mathrm{mM} \mathrm{MgCl} 2,0.1 \mu \mathrm{M}$ of each primer, and deionized water. After $5 \mathrm{~min}$ of denaturation at $95^{\circ} \mathrm{C}, 35$ thermal cycles of $45 \mathrm{~s}$ at $95^{\circ} \mathrm{C}, 45 \mathrm{~s}$ at $57^{\circ} \mathrm{C}$, and $45 \mathrm{~s}$ at $72^{\circ} \mathrm{C}$ were carried out. A final extension step at $72^{\circ} \mathrm{C}$ for $7 \mathrm{~min}$ was performed to finish the reaction. The amplification of a $306 \mathrm{bp}$ PCR product was assessed by electrophoresis (BioRad) in ethidium-bromide-stained 
$1.5 \%$ agarose gels at $100 \mathrm{~V}$ for $15 \mathrm{~min}$ and visual inspection in a benchtop transilluminator (UVP-LLC).

\section{Detection and Characterization of Pseudomonads Among Isolated Strains}

Gene gacA, a genetic marker of genus Pseudomonas, was analyzed by PCR with the primers GACA-1F (5'-TGATTAGGGTGYTAG TDGTCGA-3') and GACA-2 (5'-MGYCARYTCVACRTCRCTGST GAT-3') (IBA GmbH, Germany) according to De Souza et al. [16]. Molecular typing of the subset of gacA-positive isolates was conducted by repetitive sequence PCR using the BOX A1R primer (5'-CTACGGCAAGGCGACGCTGACG-3') (IBA GmbH, Germany) [55]. Amplification products were analyzed by electrophoresis (BioRad) in $1.5 \%$ agarose gel (Fluka), with ethidium bromide, at $100 \mathrm{~V}$ for $180 \mathrm{~min}$ in $1 \times$ TAE buffer $(0.04 \mathrm{M}$ Tris-Acetate, Sigma; 0.001 M EDTA, Sigma; $\mathrm{pH}$ 8.0). Gels were photographed in a benchtop transilluminator (UVP-LLC) using the Canon Powershot G10 with UV adapter. Gel photographs were then optimized using image treatment software GIMP 2 (GNU Image Manipulation Program, Free Software Foundation, Boston, USA). Similarity matrices of densitometric curves of the gel tracks were calculated using the Jaccard Correlation Coefficient, followed by tree construction using UPGMA algorithm.

For representative isolates of distinct BOXA1R profiles, the $16 \mathrm{~S}$ rRNA gene was amplified by PCR (Multigene TC 9600-G thermocycler, Labnet International) using the universal bacterial primers $27 \mathrm{~F}$ (5'AGAGTTTGATCCTGGCTCAG-3') and 1492R (5'-GGTTACCTT GTTACGACTT-3') (IBA GmbH, Germany) [75]. Amplification was confirmed by electrophoresis as described above. The products of amplification were sequenced at external facilities (StabVida, Portugal). Sequences were compared with sequences available in the GenBank database by using the BLAST (Basic Local Alignment Search Tool) service to determine their closest relative.

\section{RESUlts}

\section{Surfactant-Resistant Bacterioneuston}

A high relative abundance of culturable surfactant-resistant bacteria was found in estuarine bacterioneuston. $\mathrm{CFU}$ counts in SDS- or CTAB-amended media at $\mathrm{T}_{0}$ were $96.6 \%$

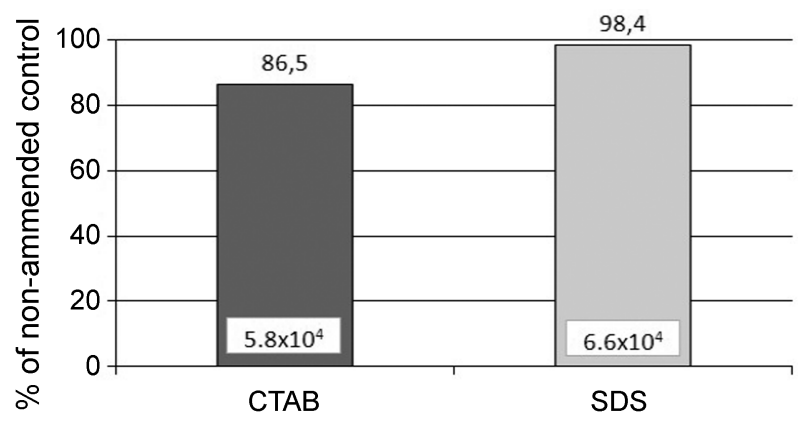

Fig. 1. Mean proportion (\%) of surfactant-resistant bacteria in selective media (PY medium $+8 \mathrm{mM}$ of SDS or $1 \mathrm{mM}$ of CTAB) in relation to the counts in nonselective (PY medium) medium, in the initial SML sample.

The absolute values (CFU/ml) are presented inside the bars.

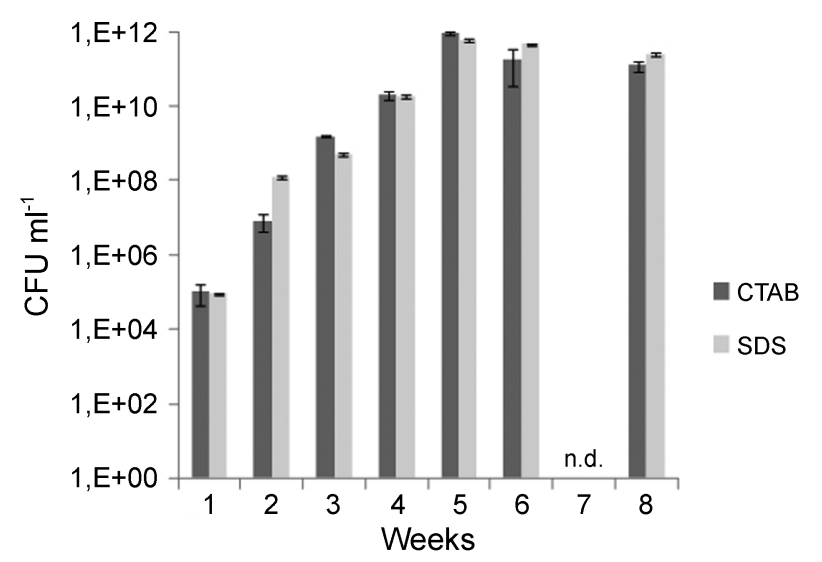

Fig. 2. Variation of the mean CFU counts in selective cultures of

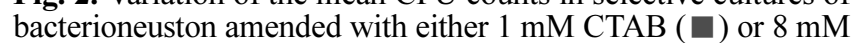
SDS ( $\square$ ) during the period of incubation (n.d., not determined).

and $89.7 \%$ of the counts obtained in nonselective medium, respectively (Fig. 1). The weekly assessment of the abundance of culturable surfactant-resistant bacteria in the selective (SDS- or CTAB-amended) liquid cultures increased by 5-6 $\log$ during the duration of the experiment (Fig. 2).

A total of 77 isolates were obtained from the 8-week selective cultures. The collection of isolates was preserved at $-20^{\circ} \mathrm{C}$ in $30 \%$ glycerol for molecular analysis. For operational reasons, only a selection of the fastest growing 53 isolates was tested for biosurfactant production and for PCR detection of $n d o$ and gacA gene sequences.

\section{Screening for Biosurfactant Production and for ndo Genes}

Upon screening by the atomized-oil assay of the set of 53 isolates, biosurfactant production was detected in 5 of them $(9.4 \%$ of the isolate set). Examples of colonies displaying the characteristic halos (positive results) and of the halos produced by chemical surfactants (positive controls) are presented in Fig. 3. The presence of the ndo gene could not be detected in any of the isolates tested by PCR with the primers PAH-RHD $\alpha$ GNF and PAH-RHD $\alpha$ GNF.

\section{Detection and Characterization of Pseudomonads}

Positive amplification with primers GACA-1F and GACA2 specific for genus Pseudomonas was obtained in 34 isolates, representing $64 \%$ of the tested set. The results of BOX-PCR analysis of the gacA positive isolates is presented in Fig. 4. The dendrogram obtained from similarity matrices of densitometric curves using UPGMA algorithm reveals the clustering of the isolates in 16 different genotypes.

Representatives of each of the 16 genotypes were sequenced. Sequencing was successful for 13 isolates. The analysis of the sequences in BLAST (Table 1) led to the identification of 4 isolates as P. putida, 2 as P. fluorescens, 1 as $P$. aeruginosa, 1 as $P$. gingeri, and 5 isolates were only 


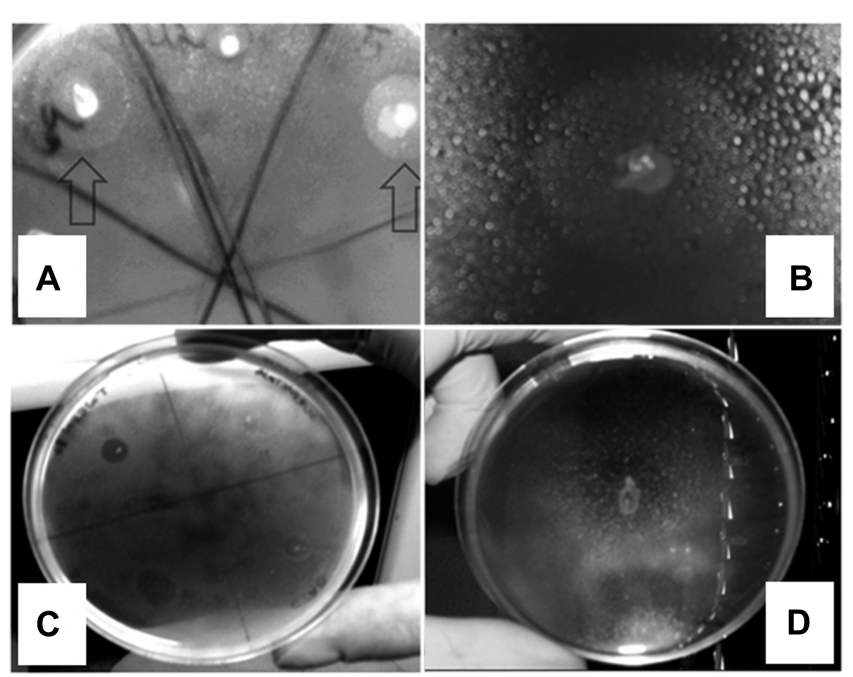

Fig. 3. Example of characteristic results of the atomized-oil assay. (A) Colonies displaying positive results for the production of biosurfactants (indicated with arrows); (B) Expanded image of a positive result; (C) Positive controls: Tween $80(8 \mu \mathrm{M})$, CTAB $(0.2 \mathrm{mM})$, SDS $(10 \mathrm{mM})$, surfactin $(15.4 \mu \mathrm{M})$; (D) Negative control (Escherichia coli $\mathrm{DH} 5 \alpha)$.

identified as Pseudomonas sp. All P. putida were obtained from the CTAB selective culture and none of them produced biosurfactant. P. fluorescens isolates were obtained in the SDS selective culture and one of them (S-5-19a) produced biosurfactant. A biosurfactant-producing $P$. aeruginosa and a nonsurfactant-producing $P$. ginger $i$ were also obtained from the CTAB selective culture. Pseudomonas sp. were isolated from CTAB and SDS selective cultures and included biosurfactant-producing and non-producing strains.

\section{Discussion}

The surface microlayer is considered a challenging environment for microorganisms, where hydrophobic compounds and surface-active substances accumulate [80]. Bacterioneuston develops at the air-water interface, and cell-surface hydrophobicity is a major determinant in the interactions of bacterial cells with this interface. The excretion of biosurfactants is considered an adaptation to interfacial life, increasing cell hydrophobicity and improving floatation and dispersion $[26,79]$. Attempts to isolate surfactantresistant bacteria from surfactant-rich environments $[7,48$, 72], and biosurfactant-producing strains from environments enriched in hydrophobic substrates [54], are documented in the literature. However, the SML remains a rather unexplored compartment in both the perspectives. Considering that the chemical environment at the estuarine SML would naturally select for surfactant-resistant bacteria, this particular biotope was used as a seed bank for the prospection and isolation of surfactant-resistant and, eventually, biosurfactantproducing strains.

\section{Bacterioneuston Resistance to Surfactants}

A high relative abundance of culturable surfactant-resistant bacteria was found in estuarine bacterioneuston. CFU counts in SDS- and CTAB-amended media in the original sample were approximately $90 \%$ of the counts obtained in nonselective medium. These values are higher than found in other surfactant-rich marine environments, determined with culture media containing $100 \mu \mathrm{M}$ and $2 \mathrm{mM}$ of CTAB [54]. Bacterioneuston tolerated concentrations of the anionic surfactant SDS and cationic surfactant CTAB at concentrations approximate to the CMC. The biofilm-like organization of bacterioneuston assemblages contributes to the resistance to surfactants because of the protection provided by the glycocalix [30]. Concentrations much lower than those tested in this work have demonstrated to strongly inhibit free-living bacteria. Values of $\mathrm{LC}_{50}$ for SDS were estimated to be $9.02 \times 10^{-3} \mathrm{mM}$ for Vibrio fischeri [47] and $5.00 \times 10^{-3} \mathrm{mM}$ for Acinetobacter junii [31]. The sewage sludge isolates Acinetobacter johnsonii and Oligotropha

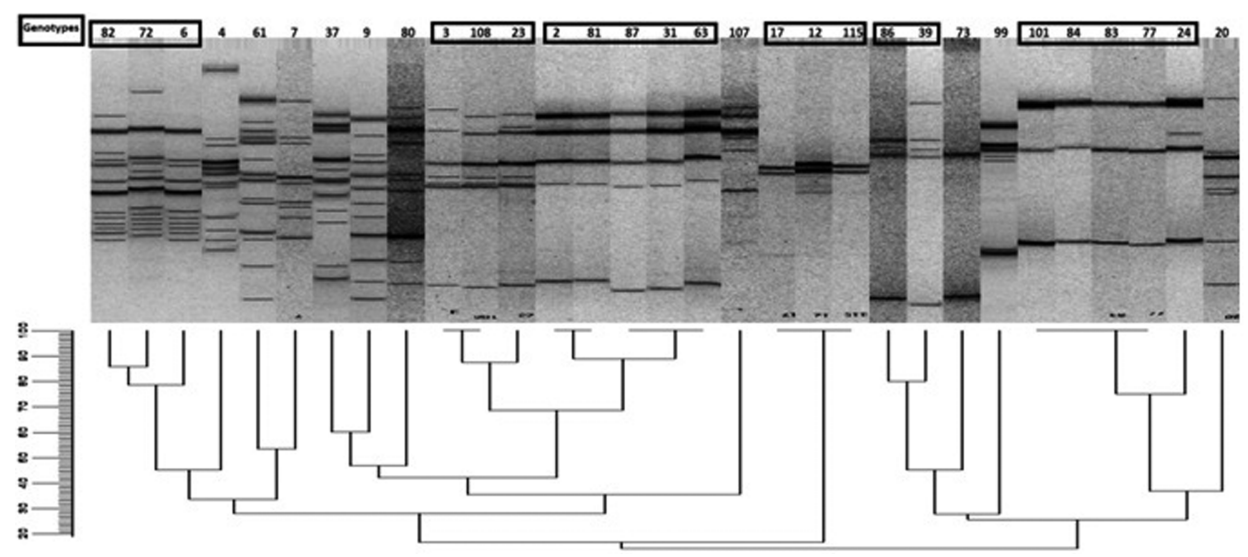

Fig. 4. Results of the molecular typing of gacA-positive isolates conducted by repetitive sequence PCR using BOX A1R primer. According to the obtained genotypes, the isolates were assigned to 16 genotypes. 
Table 1. Results of the sequencing classification using BLAST with indication of the surfactant used in the selective culture and of the production of biosurfactant as assessed by the atomized-oil assay.

\begin{tabular}{|c|c|c|c|c|c|c|}
\hline \multirow{2}{*}{$\begin{array}{l}\text { Isolate } \\
\text { code }\end{array}$} & \multirow{2}{*}{$\begin{array}{c}\text { Sequence Accession } \\
\text { No. }{ }^{\text {a }}\end{array}$} & \multirow{2}{*}{$\begin{array}{l}\text { Selective } \\
\text { culture }\end{array}$} & \multirow{2}{*}{$\begin{array}{l}\text { Biosurfactant } \\
\text { production }\end{array}$} & \multicolumn{3}{|c|}{ Closest phylogenetic relative } \\
\hline & & & & BLAST-N Identity $^{\mathrm{b}}$ & Accession No. ${ }^{\mathrm{c}}$ & $\%$ \\
\hline$C-2-4 a$ & JN033358 & CTAB & Yes & Pseudomonas sp. [49] & GQ891862 & $99 \%$ \\
\hline C-6-13 & JN033351 & CTAB & Yes & P. aeruginosa [41] & НМ067869 & $99 \%$ \\
\hline S-5-12 & JN033353 & SDS & Yes & Pseudomonas sp. [53] & GU368377 & $99 \%$ \\
\hline S-5-19a & JN033354 & SDS & Yes & P. fluorescens [18] & EF528260 & $99 \%$ \\
\hline C-0-1a & JN033360 & CTAB & No & P. putida [12] & FJ472859 & $99 \%$ \\
\hline$C-0-12 b$ & JN033359 & CTAB & No & P. putida [12] & FJ472859 & $99 \%$ \\
\hline$C-0-4 b$ & JN033352 & CTAB & No & P. putida [12] & FJ472859 & $99 \%$ \\
\hline$C-1-5$ & JN033350 & CTAB & No & Pseudomonas sp. [67] & GQ153646 & $99 \%$ \\
\hline$S-1-16 b$ & JN033356 & SDS & No & Pseudomonas sp. [67] & GQ153646 & $99 \%$ \\
\hline S-5-1a & JN033357 & SDS & No & P. segetis [67] & GQ153646 & $99 \%$ \\
\hline$C-3-5 c$ & JN033361 & CTAB & No & P. gingeri $[22]$ & AF320991 & $95 \%$ \\
\hline$C-5-2$ & JN033355 & CTAB & No & P. putida [43] & FJ611926 & $99 \%$ \\
\hline S-2-6 & JN033362 & SDS & No & P. fluorescens [42] & FJ950603 & $96 \%$ \\
\hline
\end{tabular}

${ }^{\mathrm{a}}$ GenBank sequence accession numbers of the respective isolate.

${ }^{b}$ Blast-N max identity classification.

${ }^{\mathrm{c}}$ GenBank sequence accession number of most closely related bacterial sequence(s).

carboxidovorans showed complete loss of viability during the treatment with $0.193 \mathrm{mM}$ and $1.92 \mathrm{mM}$ of CTAB, and near $50 \%$ and $20 \%$ reductions of viability with $0.70 \mathrm{mM}$ and $6.94 \mathrm{mM}$ of SDS, respectively [45]. These concentrations are 3-log lower than the concentrations used in this work.

The high proportion of surfactant-resistant bacterioneuston documented in this study can also reflect an adaptation to high levels of surfactants from natural and anthropogenic origins that accumulate at the air-water interface $[38,61]$. The samples of SML were collected near a commercial port located in Ria de Aveiro lagoon/estuary, a shipyard and a densely populated urban area. Semi-closed aquatic systems such as estuaries and lagoons tend to accumulate pollutants, namely surfactants and hydrophobic compounds [79].

Cationic surfactants are considered to be the most toxic to bacteria, especially Gram-negative bacteria, whereas anionic surfactants are less toxic, and non-ionic are considered as essentially non-toxic [59]. In this work, the difference between the relative abundances of the CTAB-resistant and SDS-resistant fractions of bacterioneuston culturable communities was not significant (ANOVA $>0.05$ ).

\section{Isolation of Surfactant-Resistant Bacteria}

Isolation of surfactant-resistant bacterioneuston from surfactant-enriched medium resulted in a total of 77 isolates resistant to SDS or CTAB at CMC concentration, 53 of which were tested for biosurfactant production. The morphological characteristics of the colonies were used for the initial selection of the isolates, with the objective of having a good representation of culturable surfactantresistant bacterioneuston phenotypes.
The atomized-oil assay was used to easily screen the set of isolates for biosurfactant production. This method is simple to perform and the results are easy to interpret. However, it is not a quantitative approach and the sensitivity of the method is still unknown. The possibility that other isolates may also produce biosurfactants, although in lower amounts, cannot be ruled out.

We hypothesized that biosurfactant-producing bacteria would be positively selected in a surfactant-enriched microcosms. Although biosurfactant-producing strains are most often retrieved from hydrocarbon enrichment cultures [74], this capacity has been frequently found among surfactant-resistant isolates [20,54]. A higher fraction of biosurfactant-producing strains could probably be achieved with different culture conditions that, in the present case, were more directed to select for surfactant resistance. Surfactant degradation and utilization is a proposed mechanism for surfactant resistance in microorganisms [76]. Biosurfactant production is often associated with the presence of hydrophobic substrates, because it plays a natural role in enhancing their bioavailability [58]. However, hydrophobic substrates are not a prerequisite for biosurfactant production [74], and biosurfactant-producing microorganisms have been isolated with other carbon sources, namely, Zobell medium [21], nutrient agar [1], minimal medium with glucose $[13,25]$, and PY medium amended with synthetic surfactants [54]. Some of the attempts to use hydrophobic carbon sources in selective or enrichment media have also achieved modest percentages of positive results, despite intense screening efforts: less than $10 \%$ of the isolates from oil-contaminated soils [48, 72, 77], $4 \%$ 
from oil-spilled seawater [46], and 9.2\% from terrestrial and marine samples [7]. A high percentage of surfactantproducing isolates $(73.8 \%)$ was retrieved from the guts of sea polychaetes [54], but the concentrations produced were very low, and since the method used for the detection was the oil-spreading assay [81], the results can hardly be compared.

Screening for genes encoding naphthalene dioxygenase (ndo), the enzyme involved in the first step of the aerobic degradation pathway of naphthalene, was unsuccessful for all isolates. However, the presence of ndo genes or the capacity for naphthalene degradation should not be excluded, because the primers employed do not cover the high diversity of known ndo genes [23] and especially not all the pathways involved in hydrocarbon degradation [44]. Moreover, catabolic genes, like $n d o$, are frequently found in mobile genetic elements, namely plasmids [62]. The lack of a selective pressure that favors the maintenance of these catabolic genes may have led to their loss during the experiment.

\section{Pseudomonads Among Surfactant-Resistant Bacterioneuston Isolates}

Pseudomonas is a genus of high biotechnological interest and the capacity of this group for the degradation of xenobiotics is widely documented in the literature $[5,6$, $24,32,35,37,43]$. A previous study conducted in Ria de Aveiro showed that Pseudomonads represent $34.5 \%$ of the culturable fraction of naphthalene-degrading bacterioneuston of the SML of the Ria de Aveiro [14]. This group is also reported as tolerant to high concentrations of anionic [35] and cationic surfactants [66] and as an efficient biosurfactant producer [9]. The present study demonstrates a high representation $(64 \%)$ of this genus in the culturable fraction of the surfactant-resistant bacterioneuston and confirms the relevance of Pseudomonads in the particular environment of the estuarine SML.

The five isolates that tested positive for biosurfactant production by the atomized oil assay [9] were identified as Pseudomonas by $16 \mathrm{~S}$ rDNA sequencing. The Pseudomonas genus is a known producer of biosurfactants, particularly rhamnolipids [10, 41, 64]. Biosurfactant-producing Pseudomonas strains have been isolated from diverse environments: oilcontaminated soils [41, 57], marine water [68], uncontaminated freshwater [34], and even air [60].

Similarity analysis between the sequenced isolates and NCBI Database revealed a high similarity with microorganisms capable of degrading hydrocarbon pollutants. Isolates C-0$12 \mathrm{a}, \mathrm{C}-0-12 \mathrm{~b}$, and $\mathrm{C}-0-4 \mathrm{~b}$, belonging to different genotypes, had a $99 \%$ similarity with Pseudomonas putida JM7 from a phenanthrene enrichment culture [12]. Isolates C-1-5 and S-1-16b revealed $>99 \%$ similarity with Pseudomonas sp. ANT-2400 isolated from a hydrocarbon enrichment culture using deep-sea $(2,400 \mathrm{~m})$ sediments from the Mediterranean
Sea [67]. Isolate S-5-19a showed $>99 \%$ similarity with Pseudomonas fluorescens AE1, a strain isolated from PAH-contaminated soil from the Baltic Sea [18]. Isolate C5-2 revealed $>99 \%$ similarity with a quinoline-degrading strain of Pseudomonas putida KT-ql-116 isolated from wastewater [43]. Isolate C-2-4a revealed high similarity with Pseudomonas sp. DIC1RS, an efficient PAH mineralizer [49]. Isolate S-5-1a showed $>99 \%$ with Pseudomonas segetis strain FR1439, a novel species described by Park et al. [52].

Isolate C-6-13 was isolated from CTAB-enrichment culture and tested positive for biosurfactant production. Although the chemical characterization of the biosurfactant detected by the atomized-oil assay was not attempted, this strain showed a $>99 \%$ similarity with Pseudomonas aeruginosa GIM 32, an efficient rhamnolipid producer [41]. Isolate S-5-1 also tested positive for biosurfactant production and showed $>99 \%$ similarity with Pseudomonas sp. JPPB B25 isolated from biofilms in copper pipes [53].

Isolates C-3-5c and S-2-6 revealed low similarity (95\% and $96 \%$, respectively) with sequences from the NCBI database. Isolate S-2-6 was more closely related to an antibiotic-resistant strain of Pseudomonas fluorescens c6 [42]. It is known that bacteria resistant to surfactants are frequently also resistant to antibiotics [33] and vice-versa [51]; that is, because resistance mechanisms, such as changes in membrane composition and efflux pumps, are similar.

The prospection of the estuarine surface microlayer such as for surfactant-resistant bacteria demonstrated the high resistance of estuarine bacterioneuston to anionic and cationic surfactants. The analysis of a set of 77 isolates retrieved from SDS- and CTAB-selective cultures revealed a high representation of Pseudomonads. The screening for biosurfactant production in a subset of 53 surfactantresistant isolates revealed this capacity in 5 isolates, all belonging to the Pseudomonads. Although ndo genes could not be detected with the PCR primers used, the similarity between the $16 \mathrm{~S}$ rDNA sequences of the isolates obtained in this work and in the NCBI database indicates high similarity with hydrocarbonoclastic and biosurfactantproducing Pseudomonas strains. This study reveals the potential of the SML as a seed bank for surfactant-resistant and biosurfactant-producing bacteria.

\section{Acknowledgments}

The authors are grateful to Fernando Fernandes for the airbrush used in the atomized oil assays and to two anonymous reviewers whose suggestions contributed to the improvement of the manuscript. This work was partially funded by the Centre for Marine and Environmental Studies (CESAM). 


\section{REFERENCES}

1. Abouseoud, M., A. Yataghene, A. Amrane, and R. Maachi. 2010. Effect of $\mathrm{pH}$ and salinity on the emulsifying capacity and naphthalene solubility of a biosurfactant produced by Pseudomonas fluorescens. J. Hazard. Mater. 180: 131-136.

2. Agogué, H., E. O. Casamayor, M. Bourrain, I. Obernosterer, F. Joux, G. J. Herndl, and P. Lebaron. 2005. A survey on bacteria inhabiting the sea surface microlayer of coastal ecosystems. FEMS Microbiol. Ecol. 54: 269-280.

3. Amirmozafari, N., F. Malekzadeh, F. Hosseini, and N. Ghaemi. 2007. Isolation and identification of anionic surfactant degrading bacteria from activated sludge. Iran. Biomed. J. 11: 81-86.

4. Attaway, H. H. and M. G. Schmidt. 2002. Tandem biodegradation of BTEX components by two Pseudomonas sp. Curr. Microbiol. 45: $30-36$.

5. Barathi, S. and N. Vasudevan. 2001. Utilization of petroleum hydrocarbons by Pseudomonas fluorescens isolated from a petroleum-contaminated soil. Environ. Int. 26: 413-416.

6. Barbieri, P., L. Palladino, P. Gennaro, and E. Galli. 1993. Alternative pathways for $o$-xylene or $m$-xylene and $p$-xylene degradation in a Pseudomonas stutzeri strain. Biodegradation 4: 71-80.

7. Batista, S., A. Mounteer, F. Amorim, and M. Tótola. 2006. Isolation and characterization of biosurfactant/bioemulsifierproducing bacteria from petroleum contaminated sites. Bioresource Technol. 97: 868-875.

8. Bruheim, P., H. Bredholt, and K. Eimhjellen. 1999. Effects of surfactant mixtures, including Corexit 9527, on bacterial oxidation of acetate and alkanes in crude oil. Appl. Environ. Microbiol. 65: $1658-1661$.

9. Burch, A. Y., B. K. Shimada, P. J. Browne, and S. E. Lindow. 2010. Novel high-throughput detection method to assess bacterial surfactant production. Appl. Environ. Microbiol. 76: 5363-5372.

10. Caiazza, N. C., R. M. Q. Shanks, and G. O'Toole. 2005. Rhamnolipids modulate swarming motility patterns of Pseudomonas aeruginosa. J. Bacteriol. 187: 7351.

11. Cébron, A., M. Norini, T. Beguiristain, and C. Leyval. 2008. Real-time PCR quantification of PAH-ring hydroxylating dioxygenase $\left(\mathrm{PAH}-\mathrm{RHD}_{\alpha}\right.$ ) genes from Gram positive and Gram negative bacteria in soil and sediment samples. J. Microbiol. Methods 73: 148-159.

12. Chang, M., T. Holoman, and H. Yi. 2008. Molecular characterization of surfactant-driven microbial community changes in anaerobic phenanthrene-degrading cultures under methanogenic conditions. Biotechnol. Lett. 30: 1595-1601.

13. Chen, C. Y., S. C. Baker, and R. C. Darton. 2007. The application of a high throughput analysis method for the screening of potential biosurfactants from natural sources. J. Microbiol. Methods 70: 503-510.

14. Coelho, F. J. R. C., S. Sousa, L. Santos, A. L. Santos, A. Almeida, N. C. M. Gomes, and Â. Cunha. 2011. Exploring hydrocarbonoclastic bacterial communities in the estuarine surface microlayer Aquat. Microb. Ecol. 64: 185-195.

15. Davey, M. E., N. C. Caiazza, and G. A. O'Toole. 2003. Rhamnolipid surfactant production affects biofilm architecture in Pseudomonas aeruginosa PAO1. J. Bacteriol. 185: 1027-1036.
16. De Souza, M., C. Huang, N. Chee, and N. Terry. 1999. Rhizosphere bacteria enhance the accumulation of selenium and mercury in wetland plants. Planta 209: 259-263.

17. Dias, J. M., J. Lopes, and I. Dekeyser. 1999. Hydrological characterisation of Ria de Aveiro, Portugal, in early summer. Oceanol. Acta 22: 473-485.

18. Edlund, A. and J. K. Jansson. 2008. Use of bromodeoxyuridine immunocapture to identify psychrotolerant phenanthrenedegrading bacteria in phenanthrene-enriched polluted baltic sea sediments. FEMS Microbiol. Ecol. 65: 513-525.

19. Franklin, M. P., I. R. McDonald, D. G. Bourne, N. J. P. Owens, R. C. U. Goddard, and J. C. Murrell. 2005. Bacterial diversity in the bacterioneuston (sea surface microlayer): The bacterioneuston through the looking glass. Environ. Microbiol. 7: 723-736.

20. Gaze, W., N. Abdouslam, P. Hawkey, and E. Wellington. 2005. Incidence of Class 1 integrons in a quaternary ammonium compound-polluted environment. Antimicrob. Agents Chemother. 49: 1802.

21. Gnanamani, A., V. Kavitha, N. Radhakrishnan, G. Sekaran, G. S. Rajakumar, and A. Mandal. 2010. Microbial biosurfactants and hydrolytic enzymes mediate in situ development of stable supra-molecular assemblies in fatty acids released from triglycerides. Colloids. Surf. B Biointerfaces 78: 200-207.

22. Godfrey, S. A. C., J. W. Marshall, and J. D. Klena. 2001. Genetic characterization of Pseudomonas 'NZI7' - a novel pathogen that results in a brown blotch disease of Agaricus bisporus. J. Appl. Microbiol. 91: 412-420.

23. Gomes, N., L. Borges, R. Paranhos, F. Pinto, E. Krogerrecklenfort, L. Mendonça-Hagler, and K. Smalla. 2007. Diversity of ndo genes in mangrove sediments exposed to different sources of polycyclic aromatic hydrocarbon pollution. Appl. Environ. Microbiol. 73: 7392.

24. Gomes, N., I. A. Kosheleva, W. R. Abraham, and K. Smalla. 2005. Effects of the inoculant strain Pseudomonas putida KT2442 (pNF142) and of naphthalene contamination on the soil bacterial community. FEMS Microbiol. Ecol. 54: 21-33.

25. Guerra-Santos, L., O. Kappeli, and A. Fiechter. 1984. Pseudomonas aeruginosa biosurfactant production in continuous culture with glucose as carbon source. Appl. Environ. Microbiol. 48: 301.

26. Hale, M. S. and J. G. Mitchell. 1997. Sea surface microlayer and bacterioneuston spreading dynamics. Mar. Ecol. Prog. Ser. 147: 269-276.

27. Harayama, S., H. Kishira, Y. Kasai, and K. Shutsubo. 1999. Petroleum biodegradation in marine environments. J. Mol. Microbiol. Biotechnol. 1: 63-70.

28. Harvey, G. W. and L. A. Burzell. 1972. A simple microlayer method for small samples. Limnol. Oceanogr. 17: 156-160.

29. Henriques, I. S., A. Almeida, Â. Cunha, and A. Correia. 2004. Molecular sequence analysis of prokaryotic diversity in the middle and outer sections of the Portuguese estuary Ria de Aveiro. FEMS Microbiol. Ecol. 49: 269-279.

30. Hoyle, B. D., J. Jass, and J. W. Costerton. 1990. The biofilm glycocalyx as a resistance factor J. Antimicrob. Chemother. 26: $1-2$.

31. Hrenovic, J. and T. Ivankovic. 2007. Toxicity of anionic and cationic surfactant to Acinetobacter junii in pure culture. Cent. Eur. J. Biol. 2: 405-414. 
32. Hubert, C., Y. Shen, and G. Voordouw. 1999. Composition of toluene-degrading microbial communities from soil at different concentrations of toluene. Appl. Environ. Microbiol. 65: 3064.

33. Ishikawa, S., Y. Matsumura, F. Yoshizako, and T. Tsuchido. 2002. Characterization of a cationic surfactant resistant mutant isolated spontaneously from Escherichia coli. J. Appl. Microbiol. 92: $261-268$.

34. Janek, T., M. Lukaszewicz, T. Rezanka, and A. Krasowska. 2010. Isolation and characterization of two new lipopeptide biosurfactants produced by Pseudomonas fluorescens BD5 isolated from water from the Arctic Archipelago of Svalbard. Bioresour. Technol. 101: 6118-6123.

35. Jovèiæ, B., J. Begovi, J. Lozo, L. Topisirovi, and M. Koji. 2009. Dynamics of sodium dodecyl sulfate utilization and antibiotic susceptibility of strain Pseudomonas sp. ATCC19151. Arch. Biol. Sci. 61: 159-164.

36. Kebbouche-Gana, S., M. Gana, S. Khemili, F. Fazouane-Naimi, N. Bouanane, M. Penninckx, and H. Hacene. 2009. Isolation and characterization of halophilic Archaea able to produce biosurfactants. J. Ind. Microbiol. Biotechnol. 36: 727-738.

37. Kostal, J., M. Suchanek, H. Klierova, K. Demnerova, B. Kralova, and D. L. McBeth. 1998. Pseudomonas C12B, an SDS degrading strain, harbours a plasmid coding for degradation of medium chain length $n$-alkanes. Int. Biodeterior. Biodegradation 42: 221-228.

38. Kozarac, Z., D. Risovic, S. Frka, and D. Mobius. 2005. Reflection of light from the air/water interface covered with sea-surface microlayers. Mar. Chem. 96: 99-113.

39. Lacal, J., F. Muñoz-Martínez, J.-A. Reyes-Darías, E. Duque, M. Matilla, A. Segura, et al. 2011. Bacterial chemotaxis towards aromatic hydrocarbons in Pseudomonas. Environ. Microbiol. 13: $1733-1744$.

40. Lakshmipathy, T. D., A. S. A. Prasad, and K. Kannabiran. 2010. Production of biosurfactant and heavy metal resistance activity of Streptomyces sp. VITDDK3 - a novel halo tolerant actinomycetes isolated from saltpan soil. Adv. Biol. Res. 4: 108-115.

41. Li, A., M. Xu, W. Sun, and G. Sun. 2011. Rhamnolipid production by Pseudomonas aeruginosa GIM 32 using different substrates including molasses distillery wastewater Appl. Biochem. Biotechnol. 163: 600-611.

42. Li, D., T. Yu, Y. Zhang, M. Yang, Z. Li, M. Liu, and R. Qi. 2010. Antibiotic resistance characteristics of environmental bacteria from an oxytetracycline production wastewater treatment plant and the receiving river. Appl. Environ. Microbiol. 76: 34443451.

43. Lin, Q. and W. Jianlong. 2010. Biodegradation characteristics of quinoline by Pseudomonas putida. Bioresour. Technol. 101: 7683-7686.

44. Luz, A. P., V. H. Pellizari, L. G. Whyte, and C. W. Greer. 2004. A survey of indigenous microbial hydrocarbon degradation genes in soils from Antarctica and Brazil. Can. J. Microbiol. 50: $323-333$.

45. Malik, A., P. Kimchhayarasy, and K. Kakii. 2005. Effect of surfactants on stability of Acinetobacter johnsonii S35 and Oligotropha carboxidovorans S23 coaggregates. FEMS Microbiol. Ecol. 51: 313-321.

46. Maneerat, S. and K. Phetrong. 2007. Isolation of biosurfactantproducing marine bacteria and characteristics of selected biosurfactant. J. Sci. Technol. 29: 781-791.
47. Mariani, L., D. De Pascale, O. Faraponova, A. Tornambè, A. Sarni, S. Giuliani, et al. 2006. The use of a test battery in marine ecotoxicology: The acute toxicity of sodium dodecyl sulfate. Environ. Toxicol. 21: 373-379.

48. Mercadé, M. E., L. Monleón, C. Andrés, I. Rodón, E. Martinez, M. J. Espuny, and A. Manresa. 1996. Screening and selection of surfactant-producing bacteria from waste lubricating oil. J. Appl. Microbiol. 81: 161-166.

49. Molina, M., N. González, L. Bautista, R. Sanz, R. Simarro, I. Sánchez, and J. Sanz. 2009. Isolation and genetic identification of PAH degrading bacteria from a microbial consortium. Biodegradation 20: 789-800.

50. Mulkins-Phillips, G. and J. E. Stewart. 1974. Effect of four dispersants on biodegradation and growth of bacteria on crude oil. Appl. Environ. Microbiol. 28: 547-552.

51. Nikaido, H. 2001. Preventing drug access to targets: Cell surface permeability barriers and active efflux in bacteria. Semin. Cell. Dev. Biol. 12: 215-223.

52. Park, Y.-D., H. Yi, K. S. Baik, C. N. Seong, K. S. Bae, E. Y. Moon, and J. Chun. 2006. Pseudomonas segetis sp. nov., isolated from soil. Int. J. Syst. Evol. Microbiol. 56: 2593-2595.

53. Pavissich, J., I. Vargas, B. Gonzalez, P. Pastén, and G. Pizarro. 2010. Culture dependent and independent analyses of bacterial communities involved in copper plumbing corrosion. J. Appl. Microbiol. 109: 771-782.

54. Plante, C. J., K. M. Coe, and R. G. Plante. 2008. Isolation of surfactant-resistant bacteria from natural, surfactant-rich marine habitats. Appl. Environ. Microbiol. 74: 5093-5099.

55. Rademaker, J., F. Louws, J. Versalovic, F. Bruijn, G. Kowalchuk, I. Head, et al. 2004. Characterization of the diversity of ecologically important microbes by rep-PCR genomic fingerprinting, pp. 611-643. In G. Kowalchuk, F. J. de Bruijn, I. M Head, A. D. L Akkermans, and J. D. van Elsas (eds.). Molecular Microbial Ecology Manual, Volumes 1 and 2, $2^{\text {nd }}$ Ed. Kluwer Academic Publishers, Dordrecht.

56. Rahman, P. K. S. M. and E. E. Gakpe. 2008. Production, characterisation and applications of biosurfactants - Review. Biotechnology 7: 360-370.

57. Rashedi, H., E. Jamshidi, M. M. Assadi, and B. Bonakdarpour. 2005. Isolation and production of biosurfactant from Pseudomonas aeruginosa isolated from Iranian southern wells oil. Int. J. Environ. Sci. Technol. 2: 122-127.

58. Ron, E. and E. Rosenberg. 2010. Role of biosurfactants, pp. 2515-2520. In K. N. Timmis (ed.). Handbook of Hydrocarbon and Lipid Microbiology. Springer, Berlin Heidelberg.

59. Rouse, J. D., D. A. Sabatini, J. M. Suflita, and J. H. Harwell. 1994. Influence of surfactants on microbial degradation of organic compounds. Crit. Rev. Environ. Sci. Technol. 24: 325370 .

60. Sahoo, S., S. Datta, D. Biswas, and R. Banik Choudhury. 2010. Biosurfactant production from $n$-paraffins by an air isolate Pseudomonas aeruginosa OCD1. J. Oleo Sci. 59: 601-605.

61. Salter, I., M. V. Zubkov, P. E. Warwick, and P. H. Burkill. 2009. Marine bacterioplankton can increase evaporation and gas transfer by metabolizing insoluble surfactants from the airseawater interface. FEMS Microbiol. Lett. 294: 225-231.

62. Sayler, G. S., S. W. Hooper, A. C. Layton, and J. M. H. King. 1990. Catabolic plasmids of environmental and ecological significance. Microb. Ecol. 19: 1-20. 
63. Sivapathasekaran, C., S. Mukherjee, R. Sen, B. Bhattacharya, and R. Samanta. 2011. Single step concomitant concentration, purification and characterization of two families of lipopeptides of marine origin. Bioprocess Biosyst. Eng. 34: 339-346.

64. Soberon-Chavez, G., F. Lepine, and E. Deziel. 2005. Production of rhamnolipids by Pseudomonas aeruginosa. Appl. Microbiol. Biotechnol. 68: 718-725.

65. Sun, N., H. Wang, Y. Chen, S. Lu, and Y. Xiong. 2008. Effect of surfactant SDS, Tween 80, Triton X-100 and rhamnolipid on biodegradation of hydrophobic organic pollutants, pp. 47304734. In IEEE International Conference on Bioinformatics and Biomedical Engineering, Shanghai, China.

66. Takenaka, S., T. Tonoki, K. Taira, S. Murakami, and K. Aoki. 2007. Adaptation of Pseudomonas sp. strain 7-6 to quaternary ammonium compounds and their degradation via dual pathways. Appl. Environ. Microbiol. 73: 1797.

67. Tapilatu, Y., M. Acquaviva, C. Guigue, G. Miralles, J. C. Bertrand, and P. Cuny. 2010. Isolation of alkane-degrading bacteria from deep-sea Mediterranean sediments. Lett. Appl. Microbiol. 50: 234-236.

68. Thaniyavarn, J., A. Chongchin, N. Wanitsuksombut, S. Thaniyavarn, P. Pinphanichakarn, N. Leepipatpiboon, et al. 2006. Biosurfactant production by Pseudomonas aeruginosa A41 using palm oil as carbon source. J. Gen. Appl. Microbiol. 52: 215-222.

69. Tiehm, A. 1994. Degradation of polycyclic aromatic hydrocarbons in the presence of synthetic surfactants. Appl. Environ. Microbiol. 60: 258 .

70. Van Hamme, J. D., A. Singh, and O. P. Ward. 2006. Physiological aspects: Part 1 in a series of papers devoted to surfactants in microbiology and biotechnology. Biotechnol. Adv. 24: 604-620.

71. Vasileva-Tonkova, E. and V. Gesheva. 2007. Biosurfactant production by antarctic facultative anaerobe Pantoea sp. during growth on hydrocarbons. Curr. Microbiol. 54: 136-141.

72. Viramontes-Ramos, S., M. Portillo-Ruiz, M. Ballinas-Casarrubias, J. Torres-Muñoz, B. Rivera-Chavira, and G. Nevárez-Moorillón. 2010. Selection of biosurfactan/bioemulsifier-producing bacteria from hydrocarbon-contaminated soil. Braz. J. Microbiol. 41: 668-675.

73. Walczak, M., W. Donderski, Z. Mudryk, and P. Skorczewski. 2000. Aromatic hydrocarbons decomposition by neustonic bacteria. Pol. J. Environ. Stud. 9: 471-474.

74. Walter, V., C. Syldatk, and R. Hausmann. 2010. Screening concepts for the isolation of biosurfactant producing microorganisms, pp. 1-13. In R. Sen (ed.). Biosurfactants. Springer Science+ Business Media, Berlin, Heidelberg.

75. Weisburg, W. G., S. M. Barns, D. A. Pelletier, and D. J. Lane. 1991. 16S Ribosomal DNA amplification for phylogenetic study. J. Bacteriol. 173: 697-703.

76. White, G. F., N. J. Russell, and M. J. Day. 1985. A survey of sodium dodecyl sulphate (SDS) resistance and alkylsulphatase production in bacteria from clean and polluted river sites. Environ. Pollut. A 37: 1-11.

77. Willumsen, P., U. Karlson, and P. Pritchard. 1998. Response of fluoranthene-degrading bacteria to surfactants. Appl. Microbiol. Biotechnol. 50: 475-483.

78. Wouther, H. and B. Dick. 2002. Rhamnolipids stimulate uptake of hydrophobic compounds by Pseudomonas aeruginosa. Appl. Environ. Microbiol. 68: 4502-4508.

79. Wurl, O., L. Miller, R. Röttgers, and S. Vagle. 2009. The distribution and fate of surface-active substances in the seasurface microlayer and water column. Mar. Chem. 115: 1-9.

80. Wurl, O. and J. P. Obbard. 2004. A review of pollutants in the sea-surface microlayer (SML): A unique habitat for marine organisms. Mar. Pollut. Bull. 48: 1016-1030.

81. Youssef, N. H., K. E. Duncan, D. P. Nagle, K. N. Savage, R. M. Knapp, and M. J. McInerney. 2004. Comparison of methods to detect biosurfactant production by diverse microorganisms. $J$. Microbiol. Methods 56: 339-347.

82. Yuan, S., S. Wei, and B. Chang. 2000. Biodegradation of polycyclic aromatic hydrocarbons by a mixed culture. Chemosphere 41: $1463-1468$. 